\title{
THE ROLE OF IMPORT DUTIES FOR A SMALL OPEN ECONOMY
}

\author{
(C) Vera Karadjova, Elena B. Gayko, Yulia P. Ten \\ University of St. Kliment Ohridski. Ohrid, Republic of Macedonia \\ Russian customs academy. Rostov-on-Don, Russian Federation \\ science-almanac@mail.ru
}

\begin{abstract}
Any national economy, regardless of its size, diversification of natural resources and products it produces, and regardless of the degree of economic development, more or less realizes interaction links with the rest of the world and cannot remain outside the process of globalization of the economic flows. Emphasis should be placed on the comparative advantages the economy has, especially if it is a small open economy. Thereby, the central role is played by the fiscal and especially the customs policy of the country, as well as the correct positioning of import duties both for the realization of the fiscal as well as for achieving the stimulus goals. Fiscal policy, positioned in the stage of redistribution of social reproduction, besides economic, also realizes political, protective, social, demographic, educational, scientific, health, cultural and other goals, while indirectly acting on the other stages of social reproduction (production, exchange and consumption). By the example of the Republic of Macedonia as a small open economy, the paper intends to illustrate the role and significance of import duties in the direction of optimizing the realization of the fiscal policy objectives.

Key words: import, economy, customs, duty, open economy.
\end{abstract}

\section{[В. Караджова, Е.Б. Гайко, Ю.П. Тен Роль импортных пошлин в развитии малой экономики от- крытого типа]}

Любая национальная экономика, независимо от ее размеров, диверсификации природных ресурсов и производимой ею продукции и независимо от степени экономического развития, более или менее осознает взаимосвязь связей с мировой экономикой, поэтому она не может оставаться вне процесса глобализации экономических потоков. Авторы подчеркивают, что ученым следует особое внимание уделять изучению сравнительных преимуществ экономик стран открытого типа. Выявлено, что именно в малых экономиках открытого типа центральную роль играет фрискальная и таможенная политика страны, а также рациональное позиционирование импортных пошлин как для реализации фискальных, так и для достижения целей стимулирования развития экономики. В статье обосновывается мысль, что фрискальная политика государства, позиционируемая в стадии перераспределения общественного воспроизводства, помимо экономической цели, также реализует политические, протекционистские, социальные, демографические, образовательные, научные, медицинские, культурные и другие цели, опосредованно действуя на этапах общественного воспроизводства (производства, обмена и потребления). На примере Республики Македонии, как малой экономики открытого типа, в статье демонстрируется роль и значение импортных пошлин в направлении оптимизации реализации целей фискальной политики.

Ключевые слова: малая экономика открытого типа, экономическая теория и практика, малая экономическая система, импортные пошлины, экономическая интеграция, таможенные органы, фрискальная политика.

Vera Karadjova - Ph.D., associate professor. Head of departments: customs and freight forwarding, management in service sector; security and finance control. University of St. Kliment Ohridski. Ohrid, Republic of Macedonia

Elena B. Gayko - M.A., associate professor of the Foreign languages dpt. Russian customs academy. Rostov-on-Don, Russian Federation

Yulia P. Ten - Ph.D. of philosophy, Professor of Management and Economic of Customs Department, Rostov Branch of Russian Customs Academy. Rostov-on-Don, Russian Federation 
Вера Караджова - доктор наук, начальник департаментов: таможни и экспедирования грузов, менеджмента в сфере услуг, безопасности и финансового контроля. Университет «Климент Охридский» г. Охрид, Республика Македония.

Гайко Елена Борисовна - старший преподаватель кафедры иностранных языков. Ростовский фрилиал Российской таможенной академии. Ростов-на-Дону, Россия.

Тен Юлия Павловна - доктор философрских наук, профрессор кафедры управления и экономики таможенного дела. Ростовский фрилиал Российской таможенной академии. Ростов-на-Дону, Россия.

Economic theory, as well as economic practice, fully confirm the hypothesis of openness of the national economies and the impossibility of autarchy (closure) in the sense of an exclusive satisfaction of the consumption needs with domestic production. There is an indispensable need for the establishment of economic relations and connections of national economies with other countries, economic groups and integration. The reasons for this assertion are multidimensional and are very often elaborated in the economic theory and confirmed in economic practice, thereby their elaboration exceeds the area of paper of this type and scope. In any case, the basic reasons for a small economy refer to complementing the production structure of the country and the influence of external economic relations on the formation and distribution of the gross domestic product. The first reason, especially expressed in small economies with limited scope or type of resources, refers to the fact that no country produces everything that is necessary to meet the needs of the economy and the population. Each country in the selection of its production structure starts from the comparative advantages and the alternative costs and is directed to the inclusion on the world market.

Small economies that need to accelerate economic development often need additional resources in the form of loans or real goods, which is one more strong reason for openness. That is, these economies often need part of foreign income to supplement domestic savings. In such circumstances, the structure and the purpose of the borrowed funds is very important, i.e. the assumption which has to be included is that the borrowed foreign income will be used for creation of economic conditions and manufacturing facilities that will be able to repay the borrowed resources.

But, the basic type of economic connection of the economies is through foreign trade, i.e. import and export of goods and services. Only in exceptional cases such as wars, economic crises and so on, a country can be brought into a state to satisfy domestic consumption only with its own production. The main reason for external economic relations among countries is limited natural resources, or the diversity of natural resources the countries dispose with. Striving to expand, to diversify domestic production, to produce as many different products, some countries have to import raw materials and inputs that do not have and to export those raw materials that have in quantities that exceed domestic needs. Different natural conditions for agricultural products also affect the connectivity of the national economy of a country with other countries. Even small economies can have specific and unique resources that can be exported to the world market or to specialize in a certain type of production and thus to engage in the international division of labour [1, $\mathrm{p}$. 365].

Among the numerous forms of international economic relations(import and export of goods, performance and using services, lending and borrowing, equity joint ventures, financial transfers, transfer of technological development etc), the basic and most important form of foreign economic relations is foreign trade relations, i.e. imports and exports of goods. In this context one of the forms of import and export is also the transfer of technical-technological progress that goes from developed to less developed countries, starting by imports of new advanced equipment, through the purchase of patents and licenses, until establishment of long-term production cooperation and joint ventures, where 
despite the additional capital in less developed countries comes a new technique, technology, new management and marketing, new markets, etc. Having that in mind, inevitably the need arises for a detailed analysis of the role, scope, structure and significance of the import and export duties, which will create a basis for the establishment of the future measures and instruments of the customs policy. The challenge is to optimize these duties according to the structure of the total budget and tax revenues with the motivation of the domestic production as well as according to the quality of satisfying the needs of the economy and the population.

The challenge of globalization for small open economies and fiscal policy

The formation of small independent states with decolonization in the 50 s and 60 s of the last century is again actualized with the changes in the 80 s and 90 s of the last century in parallel with the processes of re-privatization and increased liberalization, as well as the abolition of protectionist barriers in international trade. The transition in the 1990s in a number of small open economies, primarily in southeastern and central Europe, created new challenges for their fragile economies in terms of their successful involvement in foreign trade relations and global economic processes. At the same time, they had to bear in mind their small market capacity and the need to be involved in the world market, where the surge in foreign competition and technological challenges could have positive and also negative effects on small economies. The ability of these countries to establish and maintain a market economy, having in mind the basic economic principles and laws, basically determines their ability to catch in with contemporary processes from which they will have positive effects, or otherwise they will simply be thrown out by the centrifugal forces of relentless competitive relations on the outskirts of the world market. An important moment that needs to be emphasized is that we a talking about small, in many cases developing countries exposed to foreign competition, and at the same time referred to the necessity of linking its economic space to the narrower and wider surrounding. Moreover, the expansion of the integration of such economies should bring benefits, but also minimize the risks to domestic stability that may arise from external shocks, which is a very complex process. Many transition countries are directed to intensify development through the application of different models of foreign investment, primarily to foreign direct investment. Many transition countries are directed to intensify development through the application of different models of foreign investment, primarily to foreign direct investment. The use of this form of openness in economies has a chalenge for the structural direction of investments, for the relation among aggregate supply and aggregate demand, employment, anticipated effects (production effects, export effects, fiscal effects, etc.), but also potential risks associated with the issues of ownership structure, stability on balance sheet, external debt, potential inflation and currency risk. The point that differ the small economies of southeast and central Europe from developing countries from other parts of the world is that they have continuity in a quality and funded educational process, potential in professional staff, creativity and innovation, which is a guarantee for productive inclusion in the world competitive processes, but in the same time thay have problems in structural disparities and in some cases structural unemployment, outdated technology, lack of capital, indebtedness, low savings rate, and so on.

Foreign trade, tax and fiscal policies have an important role to play in linking economic spaces. Thereby, the main objective of fiscal policy is the selection of an optimal budget spending strategy in relation to national income and optimization of the fiscal burden in relation to fiscal capacity, in the context of economic movements and the development of the national economy. In this context, the strategy for directing fiscal instruments in direction to implementation of such set main objective of fiscal policy is of particular importance and which in one part is dedicated to stimulating domestic production, increasing the competitiveness of domestic products and encouraging exports. The stimulative effects 
of import duties are reflected and can be analyzed by the value of the raw materials which are imported by applying preferential tax rates, stimulating effects of preferential tax rates on the development of domestic agricultural and livestock production, incentive effects of preferential tax duties on the industry development, effects of preferential tax rates on the increase in the diversification of domestic products and the increase in the competitiveness of domestic products. All these effects have an impact on the national economy economic reality, especially in terms of increasing exports and foreign exchange inflows, as well as raising the quantity and quality of meeting the needs of the population.

Participation of the Customs Administration of the Republic of Macedonia in the Budget of the Republic of Macedonia

In order to illustrate the role of import duties in a small open economy, there is an overview of the share of import duties in the total budget revenues and in the total tax revenues on the example of the Republic of Macedonia. The import duties which are under the jurisdiction of the Customs Service of the country consist of several types of duties: customs; VAT from import; excises (production, import and trade); and fees. Besides on imports, some of these duties according to the appropriate regulations are charged for export or transit of goods. In the Republic of Macedonia, the VAT from import charged by the Customs Administration is usually about $89 \%$ of the total VAT collected, while the Public Revenue Office (UJP) is responsible for collection of VAT from the turnover in the country, VAT on donations, as well as for the refund of VAT (http://www.finance.gov.mk).

Table 1

Participation of the Customs Administration in the Budget of the Republic of Macedonia for 2014, 2015 and 2016

in millions of denars

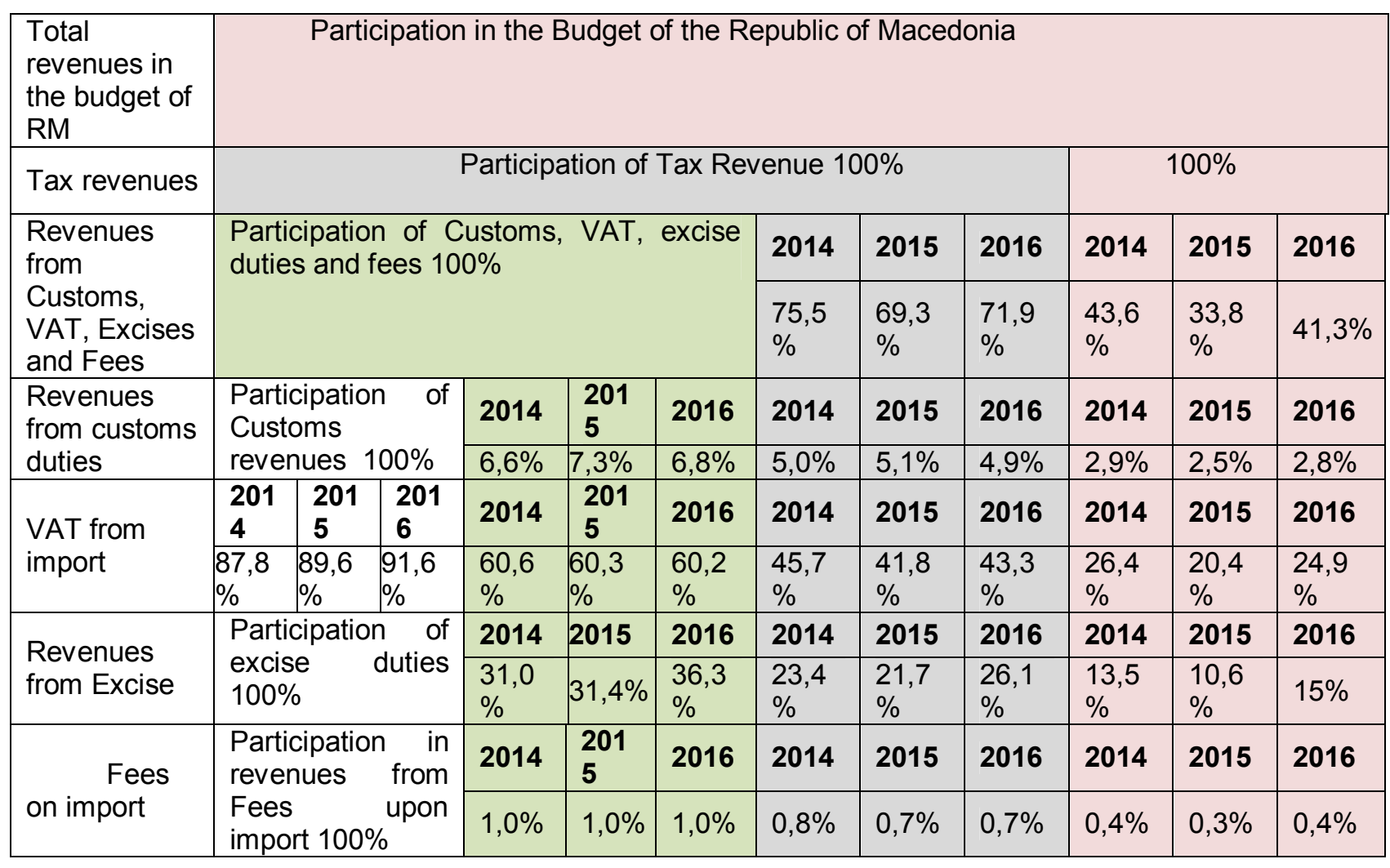

Source: own calculations based on data from http://www.mkbudget.org/prihodi/list, Annual Report of the Customs Administration of the Republic of Macedonia $(2014,2015,2016)$, Annual report of the Public Revenue Office of the Republic of Macedonia $(2014,2015,2016)$ 
The data unambiguously confirm the thesis about the importance of import duties for a small open economy, which gives the opportunity for proper positioning of fiscal and customs policies in conditions of globalization and integration processes (having in mind the multidimensional nature of fiscal and customs policies and integration processes). A much more comprehensive analysis is needed in order to determine the optimal ratio of the fiscal and incentive effects of the mentioned policies in conditions of using preferential rates, customs reliefs and exemptions and various forms of economic and trade integrations.

\section{References}

1. Mojsoski V., Karadjova V. Applied Economy, Economic System and Economic Policy. Ohrid, 2002.

2. Ministry of Finance of the Republic of Macedonia, Annual report, [Electronic resource] URL: http://www.finance.gov.mk ; (date of entrance 15.02.2017)

3. Ministry of Finance of the Republic of Macedonia, Annual report, [Electronic resource] URL: http://www.finance.gov.mk ; (date of entrance 20.04.2017)

4. Ministry of Finance of the Republic of Macedonia, Annual Report of the Customs Administration of the Republic of Macedonia, 2014, [Electronic resource] URL: http://www.mkbudget.org/prihodi/list; (date of entrance 20.04. 2017)

5. Ministry of Finance of the Republic of Macedonia, Annual Report of the Customs Administration of the Republic of Macedonia, 2015, [Electronic resource] URL: http://www.mkbudget.org/index, 2015, (date of entrance 20.04.2017)

6. Ministry of Finance of the Republic of Macedonia, Annual Report of the Customs Administration of the Republic of Macedonia, 2016, [Electronic resource] URL: http://www.mkbudget.org/index, 2016, (date of entrance 20.04.2017)

7. Ministry of Finance of the Republic of Macedonia, Annual Report of the Public Revenue Office of the Republic of Macedonia, 2016, [Electronic resource] URL: http://www.finance.gov.mk/mk/node/4446 (date of entrance 15.02.2017) 